\title{
PERTIMBANGAN HUKUM HAKIM DALAM PUTUSAN TINDAK PIDANA ASUSILA ANAK DI BAWAH UMUR
}

\author{
Rahmat Efendy Al Amin Siregar \\ (Dosen Fakultas Syariah dan Hukum, UIN Ar-Raniri Banda Aceh) \\ email: lisyuliantissiregar@yahoo.co.id
}

\begin{abstract}
There must be problems about children misbehaviour in this life. It can be divided in to two problems; they are ordinary misbehaviour and crime misbehaviour. The focuses of this research are about the consideration of the Judge to make a decision to amoral cases for the underage children, and the factors make the cases happen. The result shows that the Judge have the consideration based on the justice, giving the best to the children, and changing the children behaviour. The factors that make the crimes are the environmental society, family, economy, and the government. The judicial process of a criminal acts for children is conducted in accordance with UU Pengadilan Anak No. 11 Tahun 2012, and the preventive ways are to create a harmonious environment in family, to educate the children with combination of morality aspects. The ways to reduce are parent's control to their children behaviours, and the more intensive of ow enforcement officials to handle the criminal cases by the children under the age of.
\end{abstract}

Keywords: misbehaviour, the Judge consideration, criminal acts, and under age children.

\section{Abstrak}

Problem kenakalan anak dalam kehidupan merupakan masalah yang pasti adanya. Kenakalan anak dapat dibedakan menjadi kenakalan biasa dan kenakalan anak yang merupakan tindak pidana. Fokus dalam penelitian ini adalah, Apakah faktor-faktor pertimbangan hakim di dalam memutuskan putusan tindak pidana kejahatan asusila anak di bawah umur dan Faktor apakah yang menyebabkan terjadinya tindak pidana asusila yang dilakukan oleh anak di bawah umur. Hasil penelitian menunjukkan bahwa faktor-faktor pertimbangan hakim dalam kasus asusila anak di bawah umur yaitu keadilan, memberikan yang terbaik untuk anak, mengubah perilaku anak. Faktor yang menyebabkan terjadinya suatu tindak pidana asusila yang dilakukan anak yaitu faktor lingkungan masyarakat, keluarga, ekonomi, pemerintah. Proses peradilan tindak pidana 
untuk anak dilaksanakan sesuai dengan undang-undang Pengadilan Anak No. 11 Tahun 2012 dan cara pencegahannya yaitu menciptakan lingkungan keluarga yang harmonis dan pemberian pendidikan anak lebih ke arah moralitas, dan cara menaggulangi yaitu melalui kontrol orang tua terhadap perilaku anak dan lebih intensnya aparat penegak hukum dalam menangani kasus tindak pidana yang dilakukan anak di bawah umur.

Kata Kunci: Kenakalan anak, pertimbangan Hakim, kegiatan kriminalitas, dan anak dibawah umur.

\section{PENDAHULUAN}

Setiap negara di dunia menghadapi problem kenakalan anak dan ini tidak hanya menjadi masalah lokal, tetapi merupakan masalah sosial. Tidak berlebihan bila dikatakan bahwa problem kenakalan anak menjadi masalah bersama. Karena semua yang dilakukan oleh anak-anak merupakan tanggung jawab orangtua dan masyarakat lingkungannnya, baik di rumah, sekolah, lingkungan tempat bermain. Pemerintah dan masyarakat dituntut memiliki kebijakan dan kerjasama untuk tidak membiarkan seorang anak di bawah umur melakukan hal-hal yang berbau kejahatan.

Kenakalan anak merupakan suatu perbuatan yang dilakukan kaum remaja dan perbuatan tersebut tidak sesuai dengan peraturan yang berlaku di masyarakat. Kenakalan anak dapat dibedakan menjadi kenakalan biasa dan kenakalan tindak pidana. Kenakalan biasa lebih sederhana seperti mencoratcoret tembok orang, balapan liar sedangkan kenakalan anak yang merupakan tindak pidana, yaitu perbuatannya diancam dengan hukuman pidana, diantaranya mencuri ayam, berkelahi dengan siswa lain, membawa senjata tajam dan sebagainya. ${ }^{1}$

Banyak kejadian yang mendapat sorotan media akhir-akhir, sebuah fenomena yang memperlihatkan perilaku anak yang menjurus kepada tindak pidana kejahatan, seperti pemerkosaan, pencabulan, pencurian, perkelahian antar pelajar dan lain-lain, sehingga anak anak berhadapan dengan proses hukum seperti halnya orang dewasa. Hal ini akan berdampak tidak baik pada perkembangan anak, ini tentunya akan merugikan masa depan bangsa, oleh karena itu pemerintah dituntut melakukan upaya pencegahan agar prilaku pidana yang dilakukan anak-anak meskipun dapat dijerat dengan hukum hlm. 4.

${ }^{1}$ Gatot Supramono, Hukum Acara Pengadilan Anak, (Jakarta: Djambatan, 2005), 
namun tetap dalam upaya pemulihan / restoratif terhadap perkembangan psikologis anak.

Penyimpangan tingkah laku atau perbuatan melanggar hukum yang dilakukan oleh anak, disebabkan oleh berbagai faktor, antara lain adanya dampak negatif perkembangan yang cepat, arus globalisasi di bidang komunikasi dan informasi, kemajuan ilmu pengatuan dan teknologi serta perubahan gaya dan cara hidup sebagian orang tua, telah membawa perubahan sosial yang mendasar dalam kehidupan masyarakat yang sangat berpengaruh terhadap nilai dan perilaku anak. ${ }^{2}$ Selain itu, anak yang kurang atau tidak memperoleh kasih sayang, bimbingan dan pembinaan dalam pengembangan sikap, perilaku, penyesuaian diri, serta pengawasan dari orang tua akan mudah terseret dalam arus pergaulan masyarakat dan lingkungannya yang kurang sehat dan merugikan perkembangan pribadinya. Hubungan antara orang tua dengan anak merupakan suatu hubungan yang hakiki, baik hubungan psikologis maupun mental sepiritualnya, mengingat ciri dan sifat anak yang khas, maka dalam menjatuhkan pidana atau tindakan terhadap anak nakal diusahakan agar anak jangan dipisahkan dari orang tuanya.

Upaya penegakan hukum melalui peradilan bagi anak yang melakukan kejahatan bukan bertujuan untuk menghukum tetapi untuk memberikan kepentingan yang terbaik kepada anak (the best interests of the child). Hal ini merupakan prinsip yang seharusnya melandasi dalam setiap kebijakan dan tindakan yang dilakukan oleh siapapun, sebagaimana termaktub dalam Pasal 3 Konvensi Hak Anak bahwa, "dalam semua tindakan yang menyangkut anakanak, baik yang dilakukan lembaga-lembaga kesejahteraan sosial pemerintah atau swasta, pengadilan, para penguasa pemerintah atau badan legislatif, kepentingan terbaik harus menjadi pertimbangan utama". Apalagi dalam hal Penjatuhan hukuman (pidana badan) yang dilakukan seorang hakim terhadap anak yang merupakan tindak pidana perampasan kemerdekaannya, untuk itu penjatuhan hukuman anak hendaknya sebagai ultimum remedium, sebagai pilihan terakhir setelah melalui pertimbangan yang matang dan melibatkan pihak-pihak berkompeten. Putusan hakim itu harus diyakini bertujuan untuk memberikan atau dalam rangka kepentingan yang terbaik bagi anak.

Anak ditentukan berdasarkan perbedaan umur, yaitu bagi anak yang masih berumur 8 (delapan) tahun sampai 12 (dua belas) tahun hanya dapat

${ }^{2}$ Ibid, hlm. 12 
dikenakan tindakan, seperti dikembalikan kepada orang tuanya, ditempatkan pada organisasi sosial atau diserahkan kepada Negara, sedangkan terhadap anak yang telah mencapai umur di atas umur 12 (dua belas) tahun sampai 18 (delapan belas) tahun dapat dijatuhkan pidana. Pembedaan perlakuan tersebut didasarkan atas pertumbuhan dan perkembangan fisik, mental, dan sosial anak.

\section{KAJIAN TERORITIS}

\section{Konsep tentang Anak Di Bawah Umur}

Anak merupakan bagian dari generasi muda yang memiliki peranan strategis dan mempunyai ciri-ciri dan sifat khusus. Oleh karena itu anak memerlukan perlindungan dalam rangka menjamin pertumbuhan dan perkembangan fisik, mental dan sosial secara utuh, serasi selaras, dan seimbang. Ditinjau dari aspek yuridis maka pengertian "Anak" dimata hukum positif Indonesia lazim diartikan sebagai orang yang belum dewasa (minderjarig/ person under age), orang yang di bawah umur/ keadaan di bawah umur (minderjarigheid/inferiority) atau kerap juga disebut sebagai anak yang di bawah pengawasan wali (minderjarige ondervoordij). Namun dengan bertitik tolak kepada aspek tersebut di atas ternyata hukum positif Indonesia (ius constitutum/ ius operatum) tidak mengatur adanya unifikasi hukum yang baku dan berlaku universal untuk menentukan kriteria batasan umur bagi seorang anak. ${ }^{3}$

Apabila diperbandingkan/tinjauan komperatif ketentuan batasan umur seorang anak di negara lain maka ternyata batasan umur maksimal 18 tahun (UU 11/2012, UU 1/1974) sama dengan batasan umur dari 27 (dua puluh tujuh) negara bagian di Amerika Serikat, Kamboja, Taiwan dan Iran. Sedangkan umur maksimal 17 tahun (UU 8/1981) adalah pada 6 (enam) negara pada beberapa negara bagian di AS, Australia, Philipina, Malaysia dan Singapura. Begitu pula batas usia minimal 8 tahun di Indonesia (UU 11/2012) identik dengan rata-rata usia minimal anak di negara AS dan Australia, sedangkan untuk negara Inggris dan Belanda batas minimal 12 tahun, Kamboja umur minimal 15 tahun, Taiwan minimal 14 tahun, Iran minimal 6 tahun, Jepang dan Korea minimal 14 tahun, sedangkan Philipina, Malaysia dan singapura berumur 7 tahun. ${ }^{4}$

${ }^{3}$ Lilik Mulyadi, Pengadilan Anak di Indonesia, Teori, Praktik dan Permasalahannya, (Bandung: Mandar Maju, 2005), hlm. 3.

${ }^{4}$ Lilik Mulyadi, Pengadilan Anak..., hlm. 8. 
Anak dalam pemaknaan yang umum mendapat perhatian tidak saja dalam bidang ilmu pengetahuan, tetapi dapat ditelaah dari sisi pandang sentralistis kehidupan agama, hukum dan sosiologi yang menjadikan pengertian anak semakin rasional dan aktual dalam lingkungan sosial, sebab anak merupakan suatu anugerah dari Tuhan yang berharga dan tidak dapat dinilai dengan nominal. ${ }^{5}$

\section{Tindak Pidana}

Kejahatan merupakan perbuatan-perbuatan yang bertentangan dengan moral kemanusiaan (immoril) merugikan masyarakat (anti sosial) yang telah dirumuskan dan ditentukan dalam perundang-undangan pidana. Kejahatan yang dilakukan oleh anak timbul karena dari segi pribadinya mengalami perkembangan fisik dan perkembangan jiwa. Emosinya belum stabil, mudah tersinggung dan peka terhadap kritikan, sehingga mempengaruhi dirinya untuk bertindak yang kadang-kadang tidak umum dan di luar aturan yang berlaku di masyarakat. Di samping itu, kejahatan anak juga disebabkan karena pengaruh lingkungan.

Pangaruh kejiwaan dari individu yang hidup dalam kehidupan masyarakat, yang mengarah pada tidak keselarasan dapat membentuk normanorma yang berlaku dalam masyarakat dimana individu itu hidup. Pengaruh gangguan kejiwaan yang menimbulkan tingkah laku yang menyimpang menyebabkan individu itu tidak dapat memisahkan antara perbuatan baik atau kejahatan.

\section{Kejahatan Anak}

Kejahatan anak diartikan sebagai bentuk kejahatan yang dilakukan anak dalam title khusus dari bagian Kitab Undang-Undang Hukum Pidana dan atau peraturan perundang-undangan. Spesifikasi kejahatan anak menjadi masalah sosial dan sekaligus hukum yang telah ada dan tumbuh bersama perkembangan peradaban masyarakat, agama, sosial dan hukum. Pengelompokan utama kejahatan anak merupakan masalah sosial yang terus berkembang bersama sistim hukum sebagai bentuk solusi dari tatanan masyarakat. Asas hukum perlindungan anak dan asas kejahatan anak adalah asas usia yang belum

${ }^{5}$ Wadong, Hasan Maulana, Pengantar Advokasi dan Perlindungan Anak, (Jakarta: Grasindo, 2000), hlm. 1. 
54 | TAZKIR: Jurnal Penelitian Ilmu-ilmu Sosial dan Keislaman

Vol. 03 No. 1 Juni 2017

dewasa, sebagaimana ketentuan dalam Undang-Undang No. 11 Tahun 2012 tentang Pengadilan Anak.

\section{Kejahatan Terhadap Asusila}

Kejahatan asusila merupakan perihal susila yang berkaitan dengan adab sopan santun yang melanggar nilai-nilai moral dan etika dengan secara tidak wajar dan menyimpang dari norma agama dan hukum sehingga dapat berhadapan dengan proses hukum. Kejahatan terhadap asusila pada umumnya menimbulkan kekhawatiran atau kecemasan khususnya orang tua terhadap anak wanita karena selain dapat mengancam keselamatan anak-anak wanita yaitu perbuatan cabul, pemerkosaan dapat pula mempengaruhi proses pertumbuhan ke arah kedewasaan seksual lebih dini. Pada dasarnya asusila bertumpu pada nilai agama yaitu suatu perbuatan yang melanggar nilai agama atau perbuatan dosa/ tercela. Kejahatan terhadap asusila dalam Kitab Undang-Undang Hukum Pidana diatur pada BAB XIV Kitab Undang-Undang Hukum Pidana yang terdapat dalam Pasal 281 tentang Kejahatan Kesusilaan. Kejahatan terhadap asusila semakin rumit dalam persepsi masyarakat dengan menonjolnya era hak asasi manusia (HAM) dengan era globalisasi saat ini, nilai-nilai terhadap asusila, secara sengaja atau tidak sengaja, lambat atau cepat akan selalu terjadi pergeseran nilai, khususnya dalam penanganan hukum dan proses pembuktiannya terhadap penanganan terhadap kejahatan asusila. Dalam delik kejahatan terhadap asusila banyak menimbulkan kesulitan dalam penyelesaian baik dalam penyidikan, penuntutan maupun tahap pemgambilan keputusan, selain kesulitan dalam batasan, kesulitan pembuktian misalnya pemerkosaan atau cabul yang pada umumnya dilakukan tanpa kehadiran orang lain. ${ }^{6}$

\section{Proses Peradilan Pidana}

Berdasarkan skema dibawah ini menggambarkan proses peradilan pidana:

Peristiwa Pidana

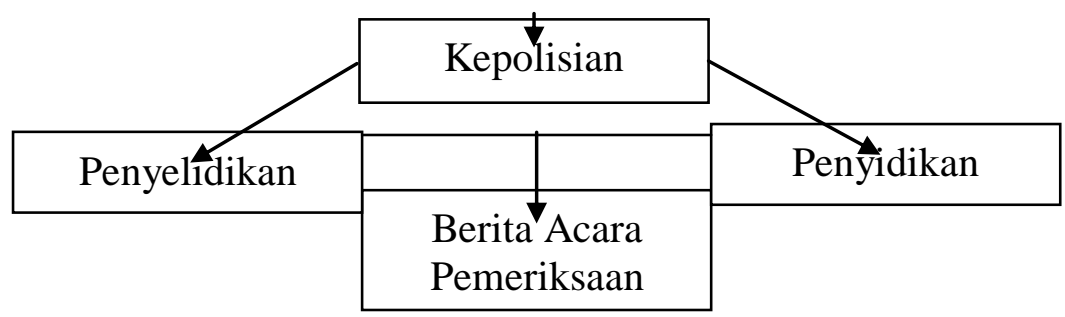

6 Leden Marpaung, Kejahatan Terhadap Kesusilaan dan Masalah Prevensinya, (Jakarta: Sinar Grafika, 1996), hlm. 7. 


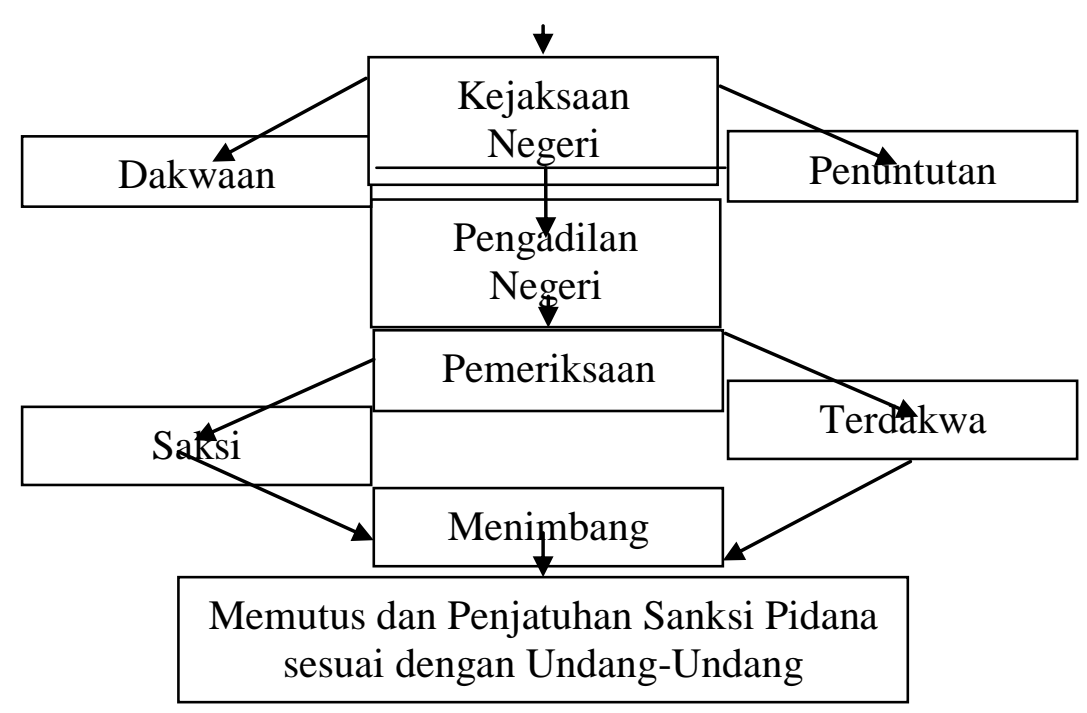

Bagan I : Proses peradilan

Berdasarkan Kitab Undang-Undang Hukum Acara Pidana, bahwa suatu proses peradilan pidana diawali dari adanya:

a) Adanya Peristiwa tindak pidana yang dilaporkan kepada kepolisian.

b) Adanya proses penyelidikan dan penyidikan yang dilakukan oleh pihak kepolisian terhadap tindak pidana.

c) Pembuatan berita acara pemeriksaan dari pihak kepolisian yang dibuat dari hasil penyelidikan dan penyidikan.

d) Masuknya surat berita acara pemeriksaan kepada Kejaksaan Negeri guna pembuatan surat dakwaan yang diteruskan penuntutan yang kemudian surat dakwaaan tersebut dimasukan kepada Pengadian Negeri.

e) Dari pengadilan negeri mengadakan pemeriksaan lebih lanjut kepada saksi (alat bukti) dan terdakwa.

f) Dari hasil pemeriksaan saksi (alat bukti) dan terdakwa kemudian hakim mendapat pertimbangan dari keterangan saksi dan terdakwa sihingga hakim dapat memutuskan dan menjatuhkan sanksi pidana demi keadilan berdasrkan Ketuhanan Yang Maha Esa dan sesuai dengan Kitab UndangUndang Hukum Pidana.

\section{Perlindungan Hukum Dalam Proses Peradilan Terhadap Anak}

Perlindungan hukum bagi anak dalam proses peradilan tidak dapat dilepaskan dari apa yang sebenarnya tujuan atau dasar pemikiran dari peradilan anak (juvenile justice) itu sendiri bertolak dari dasar pemikiran baru yang dapat 
ditentukan apa dan bagaimana hakikat wujud dari perlindungan hukum yang sifatnya diberikan kepada anak. Tujuan dan dasar pemikiran dari peradilan anak jelas tidak dapat di lepaskan dari tujuan utama untuk mewujudkan kesejahteraan anak yang pada dasarnya merupakan bagian integral dari kesejahteraan sosial. Bahwasanya kesejahteraan atau kepentingan anak berada di bawah kepentingan masyarakat, tetapi justru harus dilihat bahwa mendahulukan atau mengutamakan kesejahteraan dan kepentingan anak itu pada hakikatnya merupakan bagian dari usaha mewujudkan kesejahteraan sosial. ${ }^{7}$

Banyaknya putusan pengadilan yang berkaitan erat dengan peradilan anak dalam usaha pencegahan dan penanggulangan terhadap anak nakal. Hal ini mengundang pendapat, tanggapan atau buah pikiran dari masyarakat. Pada dasarnya sampai saat ini belum adanya undang-undang pidana khusus yang mengatur baik materi kejahatan maupun proses peradilannya. Peradilan anak dalam prakteknya belum dapat menyelesaikan perkara anak di Indonesia dan sampai sekarang eksistensinya belum memperoleh tempat yang selayaknya seperti harapan masyarakat. Peradilan anak tersebut dipengaruhi oleh faktorfaktor yang menghambat jalannya sidang perkara anak.

Faktor-faktor pokok yang mempengaruhi eksistensi Peradilan Anak adalah:

\section{a) Hukum (Perangkat Perundang-Undangan)}

Yang dimaksud dengan faktor hukum adalah perangkat hukum tertulis, terkodifikasi, yang meliputi hukum pidana anak dan hukum acara pidana anak. Perangkat hukum tersebut merupakan patokan berlangsungnya peradilan anak, karena menyangkut akan kepastian hukum dan kesebandingan hukum, karena perundang-undangan yang mengatur mengenai anak, sekarang ini tersebar dalam berbagai Undang-Undang dan pada dasarnya belum memenuhi aspirasi untuk mewujudkan suatu lembaga peradilan anak. ${ }^{8}$

\section{b) Lembaga}

Faktor yang kedua menyangkut kedudukan dan susunan lembaga peradilan sesuai Undang-Undang No. 48 Tahun 2009 tentang Pokok-Pokok

${ }^{7}$ Muladi, Barda Nawawi, Bunga Rampai Hukum Pidana, (Bandung: Alumni, 1992), hlm. 11.

8 Wahyono Agung, Rahayu Siti, Tinjauan Tentang Peradilan Anak Indonesia, (Jakarta: Sinar Grafika, 1993), hlm. 45. 
Kekuasaan Kehakiman memuat rumusan, mengingat kondisi berlangsungnya pengadilan anak diletakkan pada Badan Peradilan Umum.

Bahwa hakekat penempatan peradilan tidak berdasarkan spesialisasi sebagaimana tertera dalam penjelasan Pasal 13 Undang-Undang No. 48 Tahun 2009 Tentang Pokok-Pokok Kekuasaan Kehakiman bahwa praktek peradilan anak masih tergantung dengan peradilan umum dan ini menunjukkan realita peradilan anak di Indonesia masih seadanya.

c) Masyarakat atau partisipan lain

Peradilan anak merupakan peradilan khusus. Hal ini didasarkan kepada kebutuhan-kebutuhan yang sangat penting bagi anak-anak akan mempunyai dasar perundang-undangan yang khusus, bahwa untuk peradilannya dipakai Hukum Acara bagi orang dewasa (Undang-Undang No. 8 Tahun 1981 Kitab Undang-Undang Hukum Pidana), sedangkan sebagai pegangan/dasar Hakim dalam memutuskan adalah pasal 45, 46 dan 47 Kitab Undang-Undang Hukum Pidana. ${ }^{9}$

\section{Titik Tolak Pendekatan Masalah Perlindungan Hukum Anak}

Dasar pemikiran mengenai peradilan anak bertitik tolak pada pendekatan perlindungan hukum bagi anak dalam proses peradilan. Sekaligus menggunakan pendekatan yang berorientasi pada masalah kesejahteraan atau kepentingan anak, jelas terlihat perlunya pendekatan lain atau pendekatan khusus dalam masalah perlindungan hukum bagi anak dalam proses peradilan. Ini berarti bahwa perlu ada perhatian khusus, pertimbangan, pelayanan dan perlakuan atau perawatan khusus serta perlindungan khusus bagi anak dalam masalah hukum dan peradilan. Pengakuan dan perlunya perlakuan dan pendekatan khusus inilah yang jelas terlihat di dalam Declaration of the Rights of the Child, maupun dalam Undang-Undang Kesejahteraan anak di indonesia dan negara-negara lain di dalam Rancangan Undang-Undang Peradilan Anak di Indonesia dan Undang-Undang Peradilan Anak yang sudah ada. Pendekatan khusus dalam menangani masalah hukum dan peradilan anak ini sering terungkap di dalam berbagai pernyataan antara lain;

1. Anak yang melakukan tindak pidana atau kejahatan (juvenile offender) janganlah dipandang sebagai seorang penjahat.

${ }^{9}$ Ibid., hlm. 45. 
58 | TAZKIR: Jurnal Penelitian Ilmu-ilmu Sosial dan Keislaman

Vol.03 No. 1 Juni 2017

2. Pendekatan yuridis terhadap anak hendaknya lebih mengutamakan pendekatan persuasif-edukatif dan pendekatan kejiwaan (psikologis) untuk menghindari proses hukum yang semata-mata bersifat menghukum dan bersifat degradasi mental. ${ }^{10}$

\section{Jaminan Perlindungan Anak Dalam Proses Peradilan}

Bahwa perlindungan anak dalam proses peradilan harus juga dapat menggambarkan adanya jaminan-jaminan khusus bagi anak di bidang hukum dan peradilan. Jaminan hukum yang bersifat khusus tidak harus bertentangan dengan jaminan hukum yang umum artinya: jaminan hukum yang berlaku bagi setiap orang pada umumnya juga harus tetap berlaku bagi anak. Oleh karena itu di dalam hak-hak anak (rights of juveniles) bahwa jaminan-jaminan prosedural yang pokok/ mendasar (basic procedural safeguards) harus dijamin pada setiap tahap proses peradilan anak yaitu antara lain:

1. Hak untuk diberitahukanya tuduhan,

2. Hak untuk tetap diam,

3. Hak memperoleh penasehat hukum,

4. Hak untuk hadirnya orang tua/wali,

5. Hak untuk menghadapkan saksi dan pemeriksaan silang para saksi, dan

6. Hak untuk banding ke tingkat yang lebih atas. ${ }^{11}$

Batas usia pertanggungjawaban anak, tidak ditetapkan batas usia minimum untuk dapat dipertanggungjawabkannya seorang anak. Oleh karena itu dalam sistem hukum yang mengenal batas usia pertanggungjawaban bagi anak, permulaan batas usia pertanggungjawaban itu janganlah ditetapkan terlalu rendah dengan mengingat faktor kematangan emosional, mental dan intelektualitas anak.

Berdasarkan pendekatan modern seorang anak dipertanggungjawabkan atas perbuatannya harus berdasar tingkat kecerdasan dan pemahaman individual dari anak itu. Oleh karena itu apabila batas pertanggungjawaban ditetapkan terlalu rendah atau sama sekali tidak ditentukan, maka konsepsi pertanggungjawaban akan menjadi tidak berarti, sehubungan dengan pedoman kiranya cukup beralasan dan tidak terlalu rendah apabila Rancangan UndangUndang Pengadilan Anak (pasal 3) dan juga konsep Kitab Undang-Undang

${ }^{10}$ Muladi, Barda Nawawi, Bunga Rampai..., hlm. 14.

${ }^{11}$ Wahyono Agung, Rahayu Siti, Tinjauan Tentang..., hlm. 132. 
Hukum Pidana Baru (pasal 52) menetapkan batas usia minimal 12 tahun untuk dapat dijatuhi pidana, khususnya pidana penjara. ${ }^{12}$

\section{Upaya Pencegahan Kejahatan Anak}

Upaya pencegahan terjadinya kejahatan anak, pada dasarnya disebabkan kurangnya kesadaran dari lingkungan masyarakat terutama dari keluarga dalam memberi pendidikan kepada seorang anak. Jadi dalam menangani upaya pencegahan dan penganggulangan dari kenakalan yang dapat mengakibatkan terjadinya tindak kejahatan seorang anak, dalam masyarakat mempunyai suatu kelembagaan dalam menangani kejahatan dan kenakalan, yang merupakan suatu reaksi terhadap terjadinya kejahatan dan kenakalan, sistem kelembagaan yang dimaksud yaitu kepolisian, kejaksaan, pengadilan yang bertujuan untuk pencegahan terhadap tindak kejahatan dan kenakalan dari anak serta untuk sosialisasi petindak pidana. Dapat dikatakan sebab sosial terjadinya suatu kejahatan antara lain terdapat pada pola-pola nilai, sistem-sistem normatif, polapola perilaku yang bertentangan, standar-santar pengaruh golongan sosial, pengaruh keluarga dan kelompok sebaya, bentuk-bentuk sosial yang dapat diidentifikasi, lingkungan abstrak dan konkrit dan variabel-variabel lain.

Upaya-upaya pencegahan (preventif) melalui :

1. Pemberian bimbingan terhadap tingkah laku anak untuk jangka waktu tertentu

2. Membuka lapangan kerja yang layak untuk anak

3. Meningkatkan ketrampilan kerja anak.

Upaya-upaya penanggulangan (represif) melalui :

1. Meningkatkan kedispliman dan penanaman nilai-nilai moral yang lebih mendalam pada anak yang berperilaku menyimpang terutama dari lingkuangan keluarga.

2. Rehabilitasi penyimpangan perilaku anak di lembaga pemasyarakatan anak.

3. Aparat penegak hukum lebih inten dalam menagani kasus tindak kejahatan yang khususnya dilakukan oleh anak.

\section{Dasar Hakim Menjatuhkan Pidana Dan Bentuk-Bentuk Dari Pemidanaan}

Secara tradisional teori-teori pemidanaan pada umumnya dapat dibagi dalam dua kelompok, yaitu:

${ }^{12}$ Ibid., hlm. 133. 
60 | TAZKIR: Jurnal Penelitian Ilmu-ilmu Sosial dan Keislaman

Vol.03 No. 1 Juni 2017

\section{a. Teori Absolut atau Teori Pembalasan}

Menurut Karl O. Christiansen yang dikutip oleh Barda Nawawi dan Muladi dalam buku "Teori-teori dan Kebijakan Pidana" edisi 2 tahun 1998, bahwa teori absolut atau teori pembalasan suatu pidana dijatuhkan semata-mata karena orang telah melakukan suatu kejahatan atau tindak pidana. Pidana merupakan akibat mutlak yang harus ada sebagai suatu pembalasan kepada orang yang melakukan kejahatan. Jadi dasar pembenaran dari pidana terletak pada adanya atau terjadinya kejahatan itu sendiri.

Ciri-ciri yang terdapat di dalam teori absolut ini adalah:

1) Tujuan pidana adalah semata-mata untuk pembalasan

2) Pembalasan adalah tujuan utama dan di dalamnya tidak mengandung sarana untuk tujuan misalnya untuk kesejahteraan masyarakat

3) Kesalahan merupakan satu-satunya syarat untuk adanya pidana

4) Pidana harus disesuaikan dengan kesalahan si pelanggar

5) Pidana melihat kebelakang. ${ }^{13}$

\section{b. Teori Relatif}

Menurut Karl O. Christiansen yang dikutip oleh Barda Nawawi dan Muladi dalam buku "Teori-teori dan Kebijakan Pidana" edisi 2 tahun 1998, bahwa teori ini memidana bukanlah untuk balas dendam, melainkan untuk keadilan. Suatu pembalasan itu tidak mempunyai nilai tetapi hanya sebagai sarana untuk melindungi kepentingan masyarakat. Dasar dari pemidanaan pada teori ini adalah agar orang tersebut setelah dipidana dapat menjadi lebih baik dan berguna bagi masyarakat.

Ciri-ciri yang terdapat di dalam teori relatif ini adalah:

1) Tujuan dari pemidanaan adalah pencegahan

2) Pencegahan bukan tujuan akhir tetapi hanya sebagai sarana untuk mencapai tujuan yang lebih baik yaitu kesejahteraan masyarakat.

3) Hanya pelanggaran-pelanggaran hukum yang dapat dipersalahkan kepada pelaku saja yang memenuhi syarat untuk adanya pidana.

4) Pidana harus ditetapkan berdasarkan tujuannya sebagai alat untuk pencegahan kejahatan.

5) Pidana melihat ke depan. Pidana dapat mengandung unsur pencelaan, tetapi baik unsur pencelaan maupun unsur pembalasan tidak dapat

${ }_{13}$ Muladi, Barda Nawawi, Teori-Teori dan Kebijakan Pidana, (Bandung: Alumni, 1998), hlm. 8. 
diterima apabila tidak membantu pencegahan kejahatan untuk kepentingan masyarakat. ${ }^{14}$

\section{Faktor-Faktor yang Dapat Menimbulkan Kejahatan Asusila}

Menurut Abdul Syani dalam buku "sosiologi kriminalitas", bahwa faktorfaktor yang dapat menyebabkan tindak pidana antara lain : faktor-faktor yang bersumber dalam diri (intern) ini dapat dibagi menjadi dua bagian yakni faktor yang bersifat khusus dan faktor yang intern yang bersifat umum. Sifat khusus dalam diri individu.

1. Faktor yang terdapat dalam diri individu (intern)

Faktor yang terdapat dalam diri individu (intern) antara lain: Faktor psikologis kejiwaan seseorang atau mental yang terdapat pada seseorang juga dapat mengakibatkan terjadinya tindak kejahatan yang dikarenakan cacat mental atau gangguan kejiwaan yang diakibatkan adanya konflik mental yang berlebihan sehingga memunculkan kecenderungan untuk melakukan kejahatan.

Sifat khusus ini adalah keadaan psikologis diri individu, masalah kepribadian sering dapat menimbulkan kelakukan yang menyimpang dan apabila seseorang tertekan dengan perasaannya mempunyai kecenderungan untuk melakukan penyimpangan dan penyimpangan ini kemungkinan besar terhadap sistem sosial ataupun terhadap pola-pola kebudayaan.

Dari sifat yang khusus ini ada beberapa sifat khusus yang dapat menimbulkan kejahatan yaitu antara lain:

a. Sakit jiwa : Orang yang terkena sakit jiwa mempunyai kecenderungan untuk bersikap anti sosial dan disebabkan oleh adanya konflik mental yang berlebihan.

b. Daya emosional : Masalah emosional erat hubungannya dengan masalah sosial yang dapat mendorong seseorang untuk berbuat menyimpang. Penyimpangan ini dapat mengarah kepada suatu perbuatan kriminal atau kejahatan. Jika seseorang tersebut tidak mampu untuk mencapai keseimbangan antara emosinya dengan kehendak masyarakat.

c. Rendahnya mental : Rendahnya mental ada hubungannya dengan daya inteligensia. Jika ketinggalannya dirasakan sudah terlalu jauh dari keadaan atau standar umum, maka ia akan berusaha menebusnya dengan

14 Muladi, Barda Nawawi, Teori-Teori dan..., hlm. 8-9. 
jalan dan pikirannya sendiri yang biasanya berlebihan. Setiap usaha yang ingin mencapai sesuatu yang besar tanpa sedikit jerih payah indentik dengan tindakan kejahatan. ${ }^{15}$

d. Anomi : Secara psikologis, kepribadian manusia itu sifatnya dinamis, yang ditandai adanya kehendak, berorganisasi, berbudaya dan sebagainya.

Dalam teori anomi yang di dalamnya menterjemahkan tentang kejahatan, bahwasanya suatu kejahatan timbul dari sikap seseorang yang berada di dalam masyarakat dengan kurangnya akan kebutuhan ekonomi, sehingga dari kurangnya kebutuhan ekonomi dapat menumbuhkan sifat kekurangan dan berdampak pada kejahatan seseorang yang berusaha mencapai cita-citanya dengan melanggar undang-undang, dalam teori anomi kejahatan tumbuh dari kurangnya akan kebutuhan ekonomi terutama dari golongan ekonomi menengah ke bawah dan golongan minoritas. ${ }^{16}$

2. Faktor-faktor yang bersumber dari luar individu

Pengaruh dari faktor-faktor luar inilah yang menentukan bagi seseorang untuk mengarah kepada perbuatan jahat. Faktor-faktor yang dapat menimbulkan kejahatan (kriminalitas) yang bersumber dari luar individu ini kurang lebih meliputi hal-hal sebagai berikut:

a. Faktor Ekonomi

Banyak atau sedikitnya pengaruh faktor ekonomi terhadap timbulnya kejahatan, tetapi lebih menitikberatkan pada standar umum bahwa faktor ekonomi merupakan salah satu penyebab dari pada timbulnya kejahatan.

Untuk dapat memperjelas bahwa faktor-faktor ekonomi itu dapat mengakibatkan timbulnya kejahatan atau kriminalitas, maka dapat dirincikan sebagai berikut:

1) Pengangguran dapat dikatakan sebagai penyebab timbulnya kejahatan, yang semuanya itu dilatarbelakangi oleh kondisi buruk faktor ekonomi.

2) Tentang perubahan-perubahan harga

${ }^{15}$ Abdul Syani, Sosiologi Kriminalitas, (Bandung: Remadja Karya, 1987), hlm. 43-

45.

16 Romli Atmasasmita, Teori dan Kapita Selecta Kriminologi, (Bandung: Eresco, 1992), hlm. 25. 
Dengan adanya perubahan harga yang melambung tinggi sehingga kebutuhan seseorang tidak dapat terpenuhi maka dapat menimbulkan tindakan menyimpang yang tidak lain dari kejahatan

b. Faktor agama

Dari kurangnya pemahaman nilai-nilai agama dapat berpengaruh pada seseorang untuk melakukan tindak kejahatan karena ajaran agama mengajarkan tentang kebaikan dan menuju jalan yang benar.

c. Faktor bacaan

Bahwa bacaan-bacaan yang buruk, porno, kriminal merupakan faktor-faktor yang dapat menyebabkan timbulnya kejahatan atau kriminalitas.

d. Faktor film (termasuk televisi)

Kesan yang mungkin mendalam dari apa yang telah disaksikan dan didengar serta acara penyajian yang berbau negatif di pertunjukan di dalam film, sehingga dari apa yang ia lihat dan yang ia dengar dapat menggugah perasaan dan lebih cenderung ke dalam kriminalitas. ${ }^{17}$

\section{METODE PENELITIAN}

Penelitian ini dilakukan secara kualitatif, melakukan kajian pustaka terhadap Undang-Undang Perlindungan terhadap Anak yang berlaku di Indonesia. Data dikumpulkan dengan cara melakukan kajian terhadap Undangundang yang berlaku dan membandingkannya dengan sumber-seumber lain yang terkait, serta melakukan wawancara terkait dengan data yang dibutuhkan. Data yang diperoleh dianalisis melalui proses kualitatif, seperti membaca data, memberikan kode, dan mengelompokkan sesuai dengan pertanyaan penelitian yang dibutuhkan.

\section{HASIL PENELITIAN DAN PEMBAHASAN}

\section{Pertimbangan Hakim dalam Putusan Kejahatan Asusila yang dilakukan Anak}

Data yang dihimpun Unicef menunjukkan bahwa sepanjang tahun 2000, tercatat dalam statistik kriminal kepolisian terdapat lebih dari 11.344 anak yang disangka sebagai pelaku tindak pidana. Pada Bulan Januari hingga Mei 2002, ditemukan 4.325 tahanan anak di rumah tahanan dan lembaga pemasayrakatan di seluruh Indonesia. Lebih menyedihkan, sebagian besar $(84,2 \%)$ anak-anak ini

${ }^{17}$ Abdul Syani, Sosiologi Kriminalitas..., hlm. 43-51. 
64 | TAZKIR: Jurnal Penelitian Ilmu-ilmu Sosial dan Keislaman

Vol.03 No. 1 Juni 2017

berada di dalam lembaga pemasyarakatan untuk orang dewasa dan pemuda. Jumlah anak-anak yang ditahan tersebut, tidak termasuk anak-anak yang ditahan dalam kantor polisi (Polsek, Polres, Polda dan Mabes). Pada rentang waktu yang sama, yaitu Januari hingga Mei 2002, tercatat 9.465 anak-anak yang berstatus sebagai Anak Didik (Anak sipil, Anak Negara dan Anak Pidana) tersebar di seluruh rumah tahanan dan lembaga pemasyarakatan. Sebagian besar, yaitu 53,3\%, berada di rumah tahanan dan lembaga pemasyarakatan untuk orang dewasa dan pemuda. ${ }^{18}$

Sementara itu Komisi Nasional Perlindungan Anak, menyuguhkan fakta yang tidak menggembirakan, dimana lebih dari $90 \%$ kasus pidana anak yang disidik, dijatuhi pidana oleh hakim. Padahal hakim punya tiga kemungkinan, yaitu mengembalikan kepada orang tua, menyerahkan kepada pemerintah/dikembalikan kepada pemerintah atau dijadikan anak negara. Masih terlihat bahwa pilihan untuk mengembalikan anak kepada orang tua, tidak dimanfaatkan secara maksimal oleh hakim. ${ }^{19}$

Di Indonesia sekitar 4.277 anak berusia di bawah 16 tahun menjalani proses pengadilan. Sekitar 13.242 anak berusia 16-18 tahun dipenjara dan 98\% diantaranya laki-laki. Sedikitnya $80 \%$ kasus anak yang ditangani di Kepolisian diteruskan ke dalam proses peradilan formal, dimana $80 \%$ adalah kasus petty crimes (kejahatan ringan). Dari jumlah tersebut sekitar $83 \%$ menjalani proses peradilan dan dihukum penjara. Di Provinsi Aceh, jumlah anak yang ditahan polisi berdasarkan data BAPAS, 2004-2005 mencapai 60 orang dan 73 anak terlibat kasus makar. ${ }^{20}$

Batas usia Anak yang diatur dalam peradilan anak adalah 8 hingga 18 tahun. Pelaku tindak pidana anak di bawah usia 8 tahun diatur dalam UndangUndang Peradilan Anak: “Akan diproses penyidikannya, namun dapat diserahkan kembali pada orang tuanya atau bila tidak dapat dibina lagi diserahkan pada Departemen Sosial".

${ }^{18}$ Unicef Indonesia, Analisa Situasi Sistem Peradilan Pidana Anak (Juvenile Justice system) di Indonesia, hal ii, tt.

${ }^{19}$ M. Joni, Komisi Perlindungan Anak, 13 Oktober 2003. Diakses pada tanggal 10 Maret 2011 dari situs: http://www.pemantauperadilan.com

${ }^{20}$ Nanin P dan Hadi Utomo, Perlindungan Khusus bagi Anak, Maret 2008. Diakses pada tanggal 10 Maret 2011 dari situs: http://www.pkpa-aceh.blogspot.com Iperlindungan-khusus-bagi-anak-html 
Aparat hukum yang menjalankan proses peradilan anak adalah aparat hukum yang mengerti masalah anak terdiri dari Penyidik anak, Penuntut Umum anak, Hakim anak, Hakim Banding anak dan Hakim Kasasi anak. ${ }^{21}$ Di samping itu dalam melakukan persidangan, hakim harus berbicara dengan lemah lembut, tidak boleh marah, dan menggunakan bahasa yang mudah dimengerti oleh anak. ${ }^{22}$

Yang berwenang dapat mendampingi anak selama proses pemeriksaan anak di persidangan adalah: orang tua/wali/orang tua asuh dan BAPAS. BAPAS adalah petugas kemasyaratan yang berwenang untuk memberikan hasil penelitian atas segi ekonomi, kehidupan sosial kemasyarakatan dan motivasi anak yang melakukan perbuatan pidana. Pemberian kesempatan pembebasan bersyarat dengan masa percobaan bagi anak yang menjalani pidana, apabila telah menjalani sekurang-kurangnya sembilan bulan dan telah menjalani 2/3 dari pidana penjara yang dijatuhkan dan berkelakuan baik.

Adanya kesempatan Anak untuk dilepas dari penjara setelah menjalani hukumannya, dengan permohonan izin dari Kalapas yang menyampaikan permohonannya kepada Menteri Kehakiman dengan permohonan izin agar anak dapat dikeluarkan dari lembaga pemasyarakatan dengan atau tanpa syarat, apabila Kalapas berpendapat bahwa anak negara tidak memerlukan pembinaan lagi setelah menjalani masa pendidikannya dalam lembaga paling sedikit satu tahun dan berkelakuan baik sehingga tidak memerlukan pembinaan lagi.

\section{Pertimbangan Hakim dalam Kasus Asusila Anak}

Dalam memutuskan perkara dalam kasus asusila anak, hakim mempunyai 3 pertimbangan, yaitu :

1. Umur,

2. Keadaan fisik, dan

3. Sikap. ${ }^{23}$

Dari semua kasus asusila dan pertimbangan hakim di atas, ada 3 faktor yang hakim pertimbangkan, yaitu :

${ }^{21}$ Wawancara dengan Juwita, Pengacara di Pengadilan Negeri Banda Aceh, pada tanggal 12 Desember 2011.

${ }^{22}$ Wawancara dengan Ainal Mardhiah, Hakim di Pengadilan Negeri Banda Aceh, pada tanggal 8 Desember 2011.

${ }^{23}$ Ibid, tanggal 8 Desember 2011. 
66 | TAZKIR: Jurnal Penelitian Ilmu-ilmu Sosial dan Keislaman

Vol. 03 No. 1 Juni 2017

1. Keadilan

Keadilan merupakan tujuan utama dalam suatu persidangan. Untuk mencapai suatu keadilan, seorang hakim mendengarkan keterangan dari saksi, korban dan terdakwa supaya dalam menjatuhkan perkara benar-benar ada rasa keadilan bagi semua pihak.

2. Memberikan yang terbaik untuk anak

Memberi hak pilih untuk anak. Kalau dia masih sekolah, maka dia dikembalikan kepada orang tua/wali, dan apabila dia pengangguran dan sikap dia kurang sopan, maka dia dibina di Departemen Sosial atau dijadikan anak Negara.

3. Mengubah perilaku anak

Dalam mengubah perilaku anak juga ada pilihan, karena anak ada yang berwatak keras dan lembut. Yang lembut bisa dikembikan ke orang tua/wali dengan pengawasan BAPAS atau ke Departemen Sosial. Dan apabila anak itu wataknya keras, maka dia dipenjara dengan harapan bisa membuat anak itu kembali normal seperti semula. ${ }^{24}$

Pendapat di atas berbeda dengan Ainal Hadi dan Kadriah: pertimbanganpertimbangan hakim dalam penjatuhan hukuman terhadap anak nakal adalah sebagai berikut: ${ }^{25}$

1. Dakwaan Jaksa Penuntut Umum

Dakwaan merupakan dasar bagi pemeriksaan perkara dipersidangan. Selain memuat identitas terdakwa, juga berisikan uraian tindak pidana yang didakwakan dengan menyebut waktu dan tempat tindak pidana itu dilakukan.

Dalam pemeriksaan terhadap perkara anak, pada umumnya hakim sependapat dengan perbuatan yang didakwakan oleh jaksa kepada terdakwa, begitupun mengenai tuntutan hukuman terhadap perbuatan terdakwa yang terbukti selama proses pemeriksaan perkara di sidang pengadilan.

2. Keterangan Terdakwa

Salah satu pertimbangan hakim dalam memutuskan perkara anak nakal adalah keterangan dari pelaku kejahatan (terdakwa). Apabila dari jawabannya tidak berbelit-belit, maka ada keringanan dalam hukuman.

${ }^{24}$ Ibid, tanggal 8 Desember 2011.

${ }^{25}$ Ainal Hadi, Kadriah, Ketika Anak Terjerat Hukum, (Banda Aceh: Aceh Justice Resource Centre), hlm. 25. 
3. Keterangan Saksi

Saksi merupakan bagian yang terpenting dalam pertimbangan hakim.

4. Barang Bukti

Pengertian barang bukti adalah semua benda yang dapat dikenakan penyitaan dan yang diajukan oleh penuntut umum di depan sidang pengadilan.

Adapun faktor-faktor pertimbangan lainnya adalah sebagai berikut:

1. Mempertimbangkan mengenai peristiwanya, ialah apakah terdakwa telah melakukan perbuatan yang dituduhkan kepadanya, dan kemudian

2. Mempertimbangkan mengenai hukumnya, ialah apakah perbuatan yang dilakukan terdakwa itu merupakan suatu tindak pidana dan apakah terdakwa bersalah dan dapat dipidana, dan akhirnya

3. Mempertimbangkan mengenai pidananya, apabila terdakwa memang dapat dipidana. ${ }^{26}$

\section{KESIMPULAN}

Kesimpulan dari penelitian ini terkait faktor pertimbangan hakim dalam putusan tindak pidana kejahatan asusila anak di bawah umur sebagai berikut: Dalam memutuskan perkara dalam kasus asusila anak, hakim mempunyai 3 pertimbangan, yaitu: umur, keadaan fisik, dan sikap. Sedangkan faktor yang hakim pertimbangkan, yaitu: keadilan, memberikan yang terbaik untuk anak, dan mengubah perilaku anak, sedangkan faktor penyebab terjadinya tindak pidana asusila yang dilakukan anak di bawah umur salah satunya adalah faktor pemerintah. Kurangnya kebijakan pemerintah terhadap pers, dengan tidak adanya filter dari pemerintah terhadap mass media, dari tayangan tentang pornografi dan pornoaksi, VCD porno, majalah-majalah yang berbau foto bugil, internet (situs porno) sangat berdampak ke arah kejahatan yang pelakunya dari dewasa sampai ke anak-anak, dikarenakan kurangnya praktek pemeritah terhadap mass media yang dianggap sepele.

${ }^{26}$ Ibid., hlm. 23. 
68 | TAZKIR: Jurnal Penelitian Ilmu-ilmu Sosial dan Keislaman

Vol.03 No. 1 Juni 2017

\section{DAFTAR PUSTAKA}

Abdul Syani, Sosiologi Kriminalitas. Bandung: Remadja Karya, 1987.

Ainal Hadi, Kadriah, Ketika Anak Terjerat Hukum. Banda Aceh: Aceh Justice Resource Centre.

Gatot Supramono, Hukum Acara Pengadilan Anak. Jakarta: Djambatan, 2005.

Leden Marpaung, Kejahatan Terhadap Kesusilaan dan Masalah Prevensinya. Jakarta: Sinar Grafika, 1996.

Lilik Mulyadi, Pengadilan Anak di Indonesia, Teori, Praktik dan Permasalahannya. Bandung: Mandar Maju, 2005.

M. Joni, Komisi Perlindungan Anak, 13 Oktober 2003. Diakses pada tanggal 10 Maret 2011 dari situs: $h t t p: / / w w w . p e m a n t a u p e r a d i l a n . c o m$

Muladi, Barda Nawawi, Bunga Rampai Hukum Pidana. Bandung: Alumni, 1992. Teori-Teori dan Kebijakan Pidana. Bandung: Alumni, 1998.

Nanin P dan Hadi Utomo, Perlindungan Khusus bagi Anak, Diakses pada tanggal 10 Maret 2008.

Maret 2011 dari situs: http://www.pkpa-aceh.blogspot.com/perlindungankhusus-bagi-anak-html

Romli Atmasasmita, Teori dan Kapita Selekta Kriminologi, Bandung: Eresco, 1992.

Unicef Indonesia, Analisa Situasi Sistem Peradilan Pidana Anak (Juvenile Justice system) di Indonesia.

Wadong, Hasan Maulana, Pengantar Advokasi dan Perlindungan Anak. Jakarta: Grasindo, 2000.

Wahyono Agung, Rahayu Siti, Tinjauan Tentang Peradilan Anak Indonesia. Jakarta: Sinar Grafika, 1993. 